Norway's outright ban on hunting is the only regulatory structure to protect polar bears in that country, he says.

The United States, Greenland (under home rule from Denmark) and Canada permit limited hunting. Russia has outlawed polar bear hunts, but illegal kills are thought to be common, says Vongraven.

Canada is also considering whether to upgrade the polar bear's status. Last month, a government advisory committee announced that it would not recommend raising the bear's status to 'threatened' from 'species of concern', a move that could impact hunting activities. A decision will be made after August, when the group's final recommendations are sent to environment minister John Baird.

\section{Legal battles}

In the United States, the new listing is likely to be challenged. "There will clearly be a series of lawsuits over this that will take a long time to resolve," says Holly Doremus, an environmental lawyer at the University of California, Davis. In particular, she says, exempting federal agencies from consulting with the Fish and Wildlife Service on projects involving greenhouse-gas emissions is unlikely to withstand judicial review. "I think the Bush administration is just trying to kick this to the next administration because they don't know how to deal with it," she says.

In the meantime, prompted by other environmental lawsuits, the Fish and Wildlife Service is considering adding other species - including the emperor penguin - to the endangered or threatened species lists, partly because of threats from climate change.

And polar bears are likely to remain at the top of the international agenda for the foreseeable future. "Certainly the polar bear has become that iconic figure that will hopefully become the rallying point for that kind of discussion to take place," says Lyle Laverty, assistant secretary for Fish, Wildlife and Parks.

Next year, officials in the bear's range states plan to meet in Tromsø, Norway, to discuss management options. It will be the first such meeting in 28 years.

Rachel Courtland

\footnotetext{
1. Regehr, E. V., Lunn, N. J., Amstrup, S. C. \& Stirling, I. J. Wildl. Mgmt 71, 2673-2683 (2007).

2. Obbard, M. E. et al. Temporal Trends in the Body Condition of Southern Hudson Bay Polar Bears Climate Change Research Information Note Number 3, Ontario Ministry of Natural Resources (2006).
}

See Editorial, page 427.

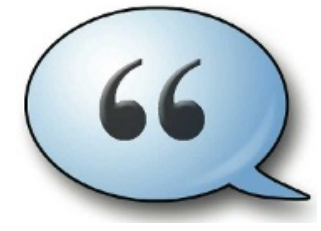

HAVE YOUR SAY

Comment on any of our news stories, online. www.nature.com/news

\title{
Whales are on the rise
}

Humpback whale numbers in the northern Pacific Ocean have ballooned to nearly 20,000 , the largest population seen since the majestic mammals were hunted nearly to extinction half a century ago.

The number of humpbacks hit an all-time low of 1,400 or even lower by 1966 , when their hunting was banned internationally. The new census, from one of the largest whale studies ever undertaken, shows that the animals have rebounded much better than expected.

"We had no idea the population could have grown this high," says John Calambokidis, a biologist at Cascadia Research Collective, a non-profit environmental research institute in Olympia, Washington, and a principal investigator on the study.

But cetologists are concerned about the estimated 900 humpbacks that migrate to the western Pacific. This subpopulation may be being hunted illegally, with some getting entangled in the nets of fishermen. Still, researchers say that the western Pacific population is increasing at more than $6 \%$ per year - roughly the same rate as humpbacks in other regions.

The three-year study, called SPLASH (Structure of Populations, Levels of Abundance and Status of Humpbacks), involved more than 400 researchers from 10 nations. Its US\$3.7-million price tag was paid for with funding from the US National Oceanic and Atmospheric Administration (NOAA), the Canadian government and private sources. It used everything from ocean-going research ships to motorized outrigger canoes to identify whales by their fluke markings, then monitor them from their feeding grounds off Canada and the Aleutian Islands to their winter and breeding grounds off Hawaii, Latin America and Asia.

"This is a great candidate to show the success of conservation programmes," says
Jay Barlow, a marine mammalogist with the NOAA Southwest Fisheries Science Center in La Jolla, California, and a study leader. The project was conceived in 2002 when US laws such as the Endangered Species Act and the Marine Mammal Protection Act were under attack by Republicans in Congress.

The report's findings may open a new dialogue about the study and regulation of humpbacks under the auspices of the International Whaling Commission. And there will probably be talks about re-evaluating the humpback's current classification as endangered.

Barlow says that revising the protection status to 'threatened' may be reasonable for the eastern-Pacific population, but that western-Pacific whales should remain listed as 'endangered'. "This study will open a discussion, which will be a long one," he says.

Japan continues 'scientific whaling' attempts on a separate population of humpbacks in the southern Pacific. Last year, the country had planned to kill nearly 1,000 humpback, fin and minke whales in the area, but international pressure reduced the take to about 550 minkes.

SPLASH also intends to furnish details about the humpback population structure, including the animals' loyalty to certain feeding or breeding regions and how this affects their survival.

Almost 8,000 humpbacks were individually catalogued, with tissue samples taken from more than 6,000 of these for DNA analysis. Already, SPLASH has revealed the existence of an unknown wintering and breeding ground - a refuge that researchers haven't yet located, but is probably in the middle of the Pacific Ocean. DNA records may play an important part in locating the area. "Finding that will be a fun project," says Barlow. Rex Dalton

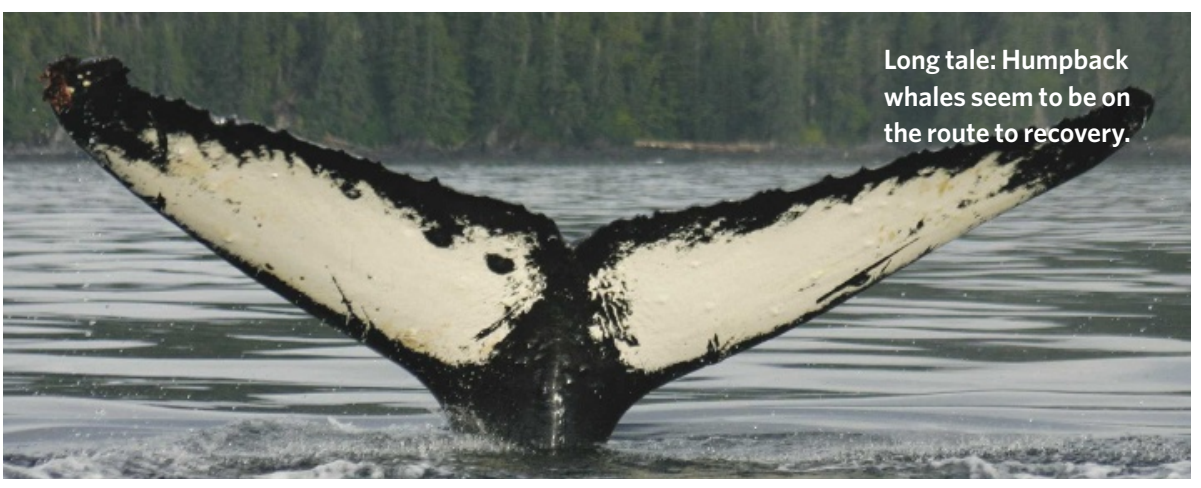

